\title{
Models of Internationalisation: The New Zealand Experience
}

\begin{abstract}
This paper examines the models of internationalisation adopted by thirty firms from New Zealand. Analysis of the international model is based on five key dimensions: firm sector and size; international market scope; market entry and servicing strategies; and speed of internationalisation. Drivers and constraints to internationalisation are also considered in the analysis. Evaluation of these dimensions over time finds evidence of both traditional 'stages' and emergent 'born (again) global' models of internationalisation, and reveals that over one third of these firms experience dramatic change to their international activities and resources initiated by divestment or change of ownership. We refer to the alternative internationalisation trajectory adopted by these firms as the 'transformational' model of internationalisation. The paper makes a contribution to the extant literature by providing synthesis of the New Zealand internationalisation and by building on our understanding of how patterns of internationalisation from a small open economy are changing in response to global environmental pressures.
\end{abstract}

Keywords: internationalisation models, SMEs, strategy, entry modes, born-globals, exporting, New Zealand

Biographical note: Joanna Scott-Kennel is Associate Professor International Management at Waikato Management School (New Zealand), and Adjunct Professor International Business, Strategy \& Enterprise Development at Aalto University School of Business (Finland). Her research interests include internationalisation of small to medium-sized enterprises (SMEs), international business strategy of multinational enterprises (MNEs), MNE external networks and the impact of foreign direct investment on industry; and Asia-Pacific business issues, and she is published in many international journals including International Business Review, Academy of Management Perspectives, Asia-Pacific Journal of Management, Journal of World Business and Management International Review. 


\section{$1 \quad$ Introduction}

The internationalisation process is of firms is an evolving phenomena of much interest to researchers, and incorporates modes and strategies employed during initial interest, entry, exploration and exploitation of foreign markets (Andersen, 1993). Traditional models of internationalisation, which date back to the 1970s, argue firms follow an incremental or stepwise approach, starting with exporting to psychically-close countries, then expanding further once they have gained more experience (Johanson and Wiedersheim-Paul, 1975). In contrast, emergent models of internationalisation demonstrate how so-called 'born global' firms rapidly enter international markets soon after inception (Chetty and Campbell-Hunt, 2003a; Knight and Cavusgil, 1996). What is not clear, in the existing literature, however, is the degree to which either of these models are adopted, or indeed, modified over time by a broader selection of firms driven to internationalise from a small, open economy context such as New Zealand.

Internationalisation, and exporting in particular, is the backbone of the New Zealand economy. Yet despite New Zealand's heavy reliance on international activities, coupled with a strong research tradition in the field of internationalisation of small firms, there is little by way of synthesis of this work at the level of the firm. In order to address this gap in the literature, this paper reviews the empirical literature on internationalisation of New Zealand firms, looking specifically for evidence of different patterns or models of internationalisation. Thirty firmlevel case studies are then selected to provide an in-depth analysis of the key dimensions of their internationalisation experience: sector and firm size, drivers and constraints, market scope, market entry and servicing mode and pace of internationalisation. The study considers how these dimensions have changed overtime for individual firms and across the sample, thus also offering a contextual rich longitudinal perspective on the international experience of New Zealand firms.

The research finds New Zealand firms tend towards early and incremental internationalisation via exporting to psychically proximate markets, although more recent internationalisation efforts by small to medium-sized enterprises (SMEs) and service firms are more likely to advance to 
more distant markets rapidly, 'leapfrogging' the traditional incremental stages. Synthesis of data from thirty case firms reveals over two thirds (21) followed a traditional, incremental internationalisation model, and nine small to medium-sized firms the emergent ('born (again) global') models. Of these thirty, eleven then either de-internationalised or sold their operations to global firms thus transforming their pattern of internationalisation. We refer to this international trajectory as the 'transformational' model. This model is most closely aligned with the 'born-again global' model researched by Bell, McNaughton, Young and Crick (2001a; 2003), with the important exception that all firms in this study were already focussed on international markets prior to the 'critical incident' that prompted transformation.

The paper is structured as follows. Following a brief review of the literature on internationalisation models, key dimensions of internationalisation are identified and evidence of models and dimensions based on the New Zealand internationalisation experience follows. The method section outlines the approach to data collection and analysis, and the results section, summarises the analysis of the case firms based on the internationalisation dimensions, and synthesizes these findings to better understand change and dynamics of New Zealand firms' traditional, emergent and transformational models of internationalisation. The paper ends with conclusions, contributions and suggestions for future research.

\section{Internationalisation models}

Two key approaches to internationalisation models have been identified in the literature, which we refer to in this paper as 'traditional' and 'emergent'. Traditional models follow an evolutionary, incremental or stepwise approach to internationalisation as firms increase their knowledge of overseas markets. The widely cited establishment chain or 'stages' theory of internationalisation (first proposed by Johanson and Wiedersheim-Paul (1975), then developed by Johanson and Vahlne (1977) of the Uppsala School), describes how companies move from domestic activities to the initial stages of (in)direct exporting, then to intermediate stages such as establishing a representative office or appointing an in-country agent, licensee or franchise, then 
finally to later stages involving the establishment of joint or wholly owned production facilities in the foreign market (for a review of the earlier research see Andersen, 1993). These stages reflect the firm's increasing international involvement expressed by way of organisational structure (ie. entry mode) and market scope as a function of increased knowledge and commitment of resources to foreign operations over time (Johanson and Vahlne, 1977; Luostarinen, 1980; Welch and Luostarinen, 1988).

Other theories support the 'traditional' model of internationalisation, many by focusing specifically on particular entry modes. Export development process models, for instance, demonstrate that even export-focussed firms grow by expanding product and market scope internationally (for reviews see Leonidou and Katsikeas, 1996) and Miesenbock, 1988). The general theory of foreign direct investment, although not a process model per se, also supports the notion that location (ie. foreign market) and organisational form (ie. entry mode) will be chosen based on transaction costs (and value), which in turn are influenced by a firm is knowledge and resource base relative to competitors (Dunning 1981, Buckley \& Casson 1993).

In contrast, firms adopting emergent models of internationalisation take accelerated, nonincremental paths to foreign markets (Bell, 1995). The 'born global' model developed from a focus on international entrepreneurship and the SME, and highlights the resource constraints associated with size along with the forces that simultaneously push and pull the firm towards international activity (Etemad, 2009; also see the special issue of Small Business Economics, edited by Etemad and Wright, 2003). Variously referred to as 'early internationalizing firms' (Rialp, Rialp and Knight, 2005), 'international new ventures' (Oviatt and McDougall, 1994; 1997), 'global start-ups' (Oviatt and McDougall, 1995) and 'born globals' (Knight and Cavusgil, 2004), such firms 'leap-frog' the sequential stages in the traditional model undertaking simultaneous entry into multiple (and often psychically-distant) markets and focusing on international, rather than domestic, markets soon after their inception (Knight, Bell and McNaughton, 2003; Knight and Cavusgil, 1996). Rapid or radical internationalisation of value chain activities (as well as trade activities) post-establishment is characteristic of such firms (Jones, 2001; Chetty and Campbell-Hunt 2004a; Coviello and Munro, 1995; Chetty and Stangl, 
2010). Managerial behaviour and network relationships can play an important role in driving and facilitating rapid internationalisation (Agndal and Chetty, 2007; Chetty and Blankenburg Holm, 2000; Etemad, 2004; Wright and Dana, 2003), by young, small, high-technology firms developing products or services for global niche markets (Jones, 1999; 2001; Coviello and Munro, 1997).

Well-established, larger firms may also adopt an emergent model of internationalisation. Bell and his co-authors refer to these firms as 'born-again globals' initiating rapid internationalisation at a later stage of their life-cycle (Bell, McNaughton and Young, 2001b; Bell, McNaughton, Young and Crick, 2003). In contrast to 'born globals', these are firms, long-established and

typically from traditional sectors that, in response to a 'critical incident' or 'episode' (such as a change of ownership, takeover or acquisition), have 'suddenly internationalised, having previously shown little or no enthusiasm for the task' (Bell et. al, 2001a: 99). These firms also may experience 'epochs' or 'episodes' of internationalisation, that is, periods of intense internationalisation followed by retrenchment in international activities (Oesterle, 1997). This phenomena, recognised in different guises by several authors, presents further challenge to the traditional model of internationalisation (Turnbull, 1997; Benito and Welch, 1997; Bell, 1995).

\section{The New Zealand experience}

New Zealand is a small island economy in the South-Pacific, distant from larger markets (the closest is Australia), and highly dependent on the activities of SMEs and trade with the rest of the world (Simmons, 2002; Rochford, 2010). Extensive and far-reaching deregulation and liberalisation initiated in 1984 transformed the New Zealand economy into one of the most open in the world (Hamilton and Dana, 2003; Chetty and Campbell-Hunt, 2004a), and placed enormous pressures on local companies to compete at international standards - both at home and abroad - without the protection of trade barriers and subsidies. The challenges of a small domestic market and distance from larger markets faced by firms internationalising from New Zealand continue to be compounded by a heavy reliance on natural resource-based industries and 
limited availability of capital (Bowen, Haworth and Wilson, 2003; Gawith, 2002; McKee, 2003). Perhaps not surprisingly, exporting from New Zealand remains concentrated in a very small number of firms (approximately 4-5 according to Simmons, 2002), and exports as a percentage of sales has been estimated to be, on average, just 17.5 per cent (median 5.9 per cent), suggesting exporting remains a 'sideline' activity for most firms (Fabling and Sanderson, 2007; Fabling, Grimes, Sanderson and Stevens, 2008; Akoorie and Enderwick, 1992).

Such compelling contextual influences have resulted in both traditional and emergent models of internationalisation being adopted, and adapted, by New Zealand firms (Hadleigh, 2005; Sweet and Nash, 2007; Chetty and Stangl, 2010; for New Zealand; and Bell, Young and Crick, 1998; Loane and Bell, 2006 for multiple countries, including New Zealand). Many firms, such as those in the agricultural sector, follow the traditional models, but remain as exporters, dealing with high volumes transported over long distances, as well as high costs associated with staying connected with customers abroad. Others, such as those in manufacturing, services and design, needing proximity to larger markets offshore, internationalise young and rely on managerial drive and capability coupled with innovation, use of networks and niche strategies to drive successful internationalisation. Many, but by no means all, of these fit the 'born global' model (Bayfield et. al., 2009; Loane, Bell and McNaughton, 2007; Chetty \& Wilson, 2003; Chetty \& Blankenburg Holm, 2000; Coviello and McAuley, 1999; Sadler and Chetty, 2000; Chetty, 1994; Loane and Bell, 2006).

Research suggests while traditional models are more typical for New Zealand firms, 'bornglobals' are increasingly common. Contrast, for example the classic large-scale study of 252 internationalising New Zealand firms by Akoorie and Enderwick (1992), which found most firms still in the early stages of a traditional, incremental model of internationalisation, with that of Chetty and Campbell-Hunt's (2004a) study, which finds firms internationalising after 1984 (post deregulation) are more likely to be 'born-globals'. The authors find 10 of the 16 firms under study follow a traditional model (of these six are regional (Australasia) and four are global), and six are 'born-globals', having internationalised within two years of inception with a strong focus on global markets. In another small scale study, Sweet and Nash (2007) also find 
evidence of firms adopting both traditional and emergent (born-global) models. The traditional firms, however, differ in that internationalisation was qualified by the objective of retaining higher value added activities, such as R\&D, in New Zealand. The authors also identify an 'acquisition' model which aims to achieve international growth through the purchase of other companies, and a 'product model' where a trade sale was seen as an objective to gain maximum value from an idea or concept (and brand). The idea of a 'trade sale' prompting internationalisation of innovation, resources or operations has been identified by Hamilton and Chow, 1993; Davenport, 2009; and Scott-Kennel and Akoorie, 2004). Scott-Kennel (forthcoming) finds for most firms their decision to sell was not 'reactive', rather it emerged from the desire to gain to take advantage of international opportunities and in most cases, it is probable that the firm's success in international markets captured the attention of would-be buyers rather than firms selling up out of necessity (ie. for survival) or being subject to hostile takeovers.

Some studies consider differentiating factors between models, for instance, Chetty and Stangl (2010) in a study of 10 software firms, find those rapidly internationalising have diverse network relationships and radical innovation, while those following a more traditional model have limited networks and incremental innovation. Similarly, in their study of high performing firms, Campbell-Hunt et al. (2001) find evidence of three phases of internationalisation, but not strictly in line with the stages identified in the traditional model: namely, 'entry and rapid growth', where the firm's focus in on keeping up with demand and organisational restructuring to cope with growth; 'sow and reap' where the firm explores diversified product and market opportunities internationally; and 'focus and grow' where the best opportunities are pursued and focus is on sustained competitive advantage and growth.

Echoing trends towards emergent models by New Zealand firms, recent research has focussed on the 'born global' firm. In line international research, the 'born global' model in New Zealand is most closely associated with young, innovative, high-tech or knowledge-intensive firms, which require rapid and timely internationalisation soon after establishment (Coviello and Munro, 1995; Chetty and Campbell-Hunt 2004a). While economic reform (post 1984) prompted some 
firms to go global (for example the removal of import tariffs in the apparel industry (Chetty, 1999; Dana et al. 2007; Chetty and Campbell-Hunt 2004a), experiential learning, innovative products with global potential, business networks and a focus/niche strategy have supported rapid internationalisation (Coviello and Munro, 1997; Loane and Bell, 2006; Loane et al., 2007). Bell and his co-authors (2001a; b; 2003) who argue that firms from small, open economies may in fact establish with the purpose of internationalising from inception, also find evidence of 'born again globals' internationalising from New Zealand.

\section{Dimensions of internationalisation}

Drawing on our brief review of models of internationalisation, we propose a number of dimensions that can be used as a basis for defining the internationalisation model adopted (see Taylor and Jack, 2011 and Chetty and Campbell-Hunt 2004a for similar dimensions). These are size and sector of the firm (as control dimensions); the timing and speed (pace) of internationalisation; the choice of international markets (incorporating both geographic and psychic distance as well as overall scope of market coverage globally); and organisational structure (i.e. referring to market entry and servicing modes). We also include in this study, key influences on firm internationalisation in the form of drivers and constraints to internationalisation ( e.g. push and pull factors, triggers and motives which can be environmentor firm-specific). These dimensions are illustrated in Figure 1, and guide the discussion of New Zealand evidence in the following section, as well as the analysis of the results later in the paper.

*Figure 1 about here*

\subsection{Timing and speed}

As exporters from a small domestic market, New Zealand firms have traditionally tend to take an early (i.e. when the firm is still young and small relative to international competitors) and incremental approach to internationalisation. As the majority of New Zealand studies are based on single or multiple case studies, it is difficult to assess the extent to generalise to all firms, however, the sum of existing evidence seems to indicate that while the majority of firms take a 
gradual approach to internationalisation, 'born globals' or rapid internationalising firms are becoming more common (Bell et al., 2001a; Chetty and Stangl, 2010; Gerschewski, 2007; Jaeger and Rudzki, 2007). Loane et al. (2007), for instance, find of the thirty young New Zealand SMEs in their sample, 63 per cent began exporting in the first two years, and there is more evidence of 'born again firms' in New Zealand than in other countries. Chetty and Campbell-Hunt (2004a) find the 'born global' model more common for firms established in the post-deregulation period (after 1984).

There is also evidence that New Zealand firms are reactive and intermittent exporters. Fabling and Sanderson (2007) find that of the 13,758 New Zealand firms that exported at some point between 1996 and 2005, 30 per cent exported in only one year, a further 25 per cent exported in less than 4 of these years and over half of all firm-level export relationships ended after a single year. Bayfield et al. (2009) found 58 per cent of a sample of 60 firms driven by reactive factors, supporting earlier evidence of a reactionary approach to strategy (see Gerschewski, 2007 for manufacturing SMEs); Castalia Strategic Advisors, 2007 for large firms); and Alon, Dana and Jenkins, 2009).

\subsection{Market scope}

Market selection by New Zealand firms - both traditional and emergent firms alike - appears driven by psychic and physical proximity, at least for initial exporting efforts (Campbell-Hunt et. al., 2001; Chetty and Campbell-Hunt, 2004a; Chetty and Stangl, 2010; Sadler and Chetty, 2000). Forays into new or more distant markets, including those in Asia (with China now New Zealand's second largest trading partner), are much more frequent than in the past when the focus was almost solely the traditional markets of the UK, the US and Australia (the UK accounted for 85 per cent of New Zealand exports in 1910, this percentage only fell under 50 per cent in 1962. Today, the UK receives less than 4 per cent of all New Zealand exports, while Australia receives one quarter (www.nzte.govt.nz). This balance is confirmed by a study of 96 manufacturing SMES, which finds Australia was by far the most frequent country for starting exporting, representing 57 per cent of the sample firms, followed by the U.S. (10 per cent), the United Kingdom and Pacific Islands (both 5 per cent each) (Gerschewski, 2007). 
The overall market scope of New Zealand firms, however, is low. Fabling and Sanderson (2007), noting that Australia, U.S., Japan, China and U.K. were the top destinations for New Zealand exports over the period 1988-2005, find the majority of growth in product-market relationships (87 per cent) came from ongoing exports to the same countries, with only 18 per cent of growth from relationships in new countries. Earlier research confirms this concentration of market scope. Akoorie and Enderwick (1992) find, for 87 per cent of the mainly small firms in their sample, 75-100 per cent of overseas sales are accounted for by their five most important markets, 50 per cent relied on a focused strategy within one or two target markets and 44 per cent of companies target only one to two countries when marketing a new product abroad, while three quarters addressed five or less. Deng, Duffy and Harrison (1995) found half the respondents to their survey were involved in fewer than two foreign markets and highlighted the risks from such low diversification. It also appears that New Zealand firms tend to have fewer export markets than firms from Australia, Canada and Ireland (Loane et al. 2007). There are however, notable exceptions, such as large scale exporting firms whose products reach a broad range of markets through local or foreign distributors/wholesalers or those who have their own distribution networks (e.g. Fonterra, Fisher \& Paykel) internationally, as well as born globals, who focus on niche markets globally.

\subsection{Entry modes}

The literature suggests New Zealand firms tend to favour low-risk/cost modes. The majority of empirical studies, including surveys, case studies and those based on statistical data gathered at a national level, focus on exporters and exporting (Vercoe, 2007; Nees and Nixon, 2005; Fabling and Sanderson, 2007; Gawith, 2002; Infometrics, 1999). This emphasis reflects that fact that many New Zealand firms employ exporting as their primary or sole internationalisation mode, either directly or via overseas sales agents (Akoorie and Enderwick, 1992; Bayfield et al., 2009). Deng et al. (1995), for instance, find just 22 percent of firms used more advanced modes involving overseas sales offices, joint ventures, and sales or production subsidiaries. Other studies have found even lower proportions of firms undertaking foreign direct investment (FDI) (4 per cent of manufacturing SMEs in Gerschewski's (2005) study, 8 per cent in Shaw and 
Darrock (2004); 8 per cent in Bayfield et al. 2009; also see Cooling, 1995; Bollard and Cremer, 1999; and Deloitte, 2008 for more on outward FDI by New Zealand firms). This exporting focus seems common to both traditional and emergent firms, as Chetty and Campbell-Hunt (2004a) conclude, that, most of their traditional counterparts, 'born global' firms from New Zealand have not progressed to direct equity modes of internationalisation (ie. FDI).

SMEs, in particular, rely on exporting, reducing costs and risks by limiting FDI to small sales offices, licensing their product or by forming a joint venture or an alliance with a foreign partner. In their study of 561 small, entrepreneurial firms, for instance, Shaw and Darrock (2004) find 58 per cent of firms operate overseas by means of direct exports; 33 per cent use agents and 30 per cent use overseas distribution agreements; 13 per cent use joint ventures and international strategic alliances, but only 8 per cent opt for overseas sales operations through FDI. Use of the internet and outsourcing are also common complementary strategies to exporting (Scott-Kennel, 2008; Jaeger and Rudzki, 2007; Knight et al., 2003).

Networks appear to be a particularly important mode for the early and rapid internationalisation of SMEs (Chetty and Campbell-Hunt, 2003a; 2004a). Determination and drive of the founder complemented by direct and personally maintained network relationships help overcome resource limitations in early stages of internationalisation. Chetty and Campbell-Hunt (2003b) assert that the speed of international success can be a destablizing factor for SMEs, and argue that business networks offer the only vehicles for sudden internationalisation where a specialised or focus strategy is employed and great increases in capability are required to go global. Conversely, Berg and Hamilton (1998) argue networks and strategic relationships with network partners can be difficult to manage and fail to meet expectations.

\subsection{Drivers and constraints}

Drivers and constraints associated with the internationalisation of New Zealand firms generally fall into one of two groups. The first are those associated with the location-specific characteristics of small, open economies and New Zealand-specific issues (Gawith, 2002; 
Andrew Fletcher Consulting, 2006) such as distance from key markets (Skilling, 2001; Simmons, 2002; Skilling and Boven, 2006), credibility (Fabling and Sanderson, 2008), limited availability of local capital (Simmons, 2002) and (lack of) government support (e.g. tax benefits) (Jaeger and Rudzki, 2007; Deloitte, 2008; Enderwick and Scott-Kennel, 2009; Bayfield et al., 2009; Alon et. al., 2009; Dana, Grimwood and William, 2009), and economic reform (i.e. the removal of tariffs) (Chetty, 1999; Dana, Hamilton and Pauwels, 2007). The primary driver for international expansion from a locational perspective is to achieve growth, and eventually profitability, outside the restricted home market (Deloitte, 2008; Akoorie \& Enderwick, 1992).

The second group of drivers and constraints to internationalisation are associated with firmspecific factors (Cooling, 1995; Castalia Strategic Advisors, 2007; MED, 2007; Enderwick and Ronayne, 2004) such as financial resources (McKee, 2003); management attitudes, knowledge and capabilities (Andrew Fletcher Consulting, 2006; NZTE, 2007; Jaeger and Rudzki, 2007; Loane et al., 2007); pre-export readiness (Gerschewski, 2007; Deloitte, 2008); access to business networks and collaboration (Chetty, 1994; Coviello and Munro, 1995; 1997; Coviello and Martin, 1999; Chetty and Blankenburg Holm, 2000; Chetty and Wilson, 2003; Kingshott and Pickering, 2005; Loane and Bell, 2006; MED, 2007; Agndal and Chetty, 2007); and use of niche strategies.

\subsection{Size and Sector}

As most of internationalising New Zealand firms are SMEs by international standards, the majority of research findings apply to smaller firms, although few studies make size comparisons the focus (Akoorie and Scott-Kennel, 2005). The main constraints to internationalisation for SMEs are finance and cost-related factors, the high costs of selling abroad, limited access to capital, limited knowledge of overseas market opportunities and the lack of New Zealand government assistance/incentives to export (Shaw and Darrock; 2004; OECD/APEC, 2007; Akoorie and Enderwick, 1992). Smaller firms are more likely to use personal connections and networks to support internationalisation (Kingshott and Pickering, 2005). Studies of larger firms suggest they are more likely to use a variety of methods to operate offshore, such as establishing distribution subsidiaries, or employing distributors and having several offshore bases for larger 
firm (MED, 2007). Access to talented managers and skilled employees is a major concern for larger firms (MED, 2007; Deloitte, 2008).

In terms of sector, exports of agricultural products have always accounted for a significant proportion of New Zealand's aggregate export value. In 2011, trade in commodities accounted for three quarters of all exports from New Zealand, and one quarter of these exports were accounted for by dairy products alone, with meat and forest products accounting for a further 20 per cent (www.statsnz.govt.nz). Exporting trends reveal increasing concentration in agricultural exports and services, but a decline in exports of manufactured goods (although manufactures are becoming higher value-added). Exports of services, and commercial services, in particular, are also increasing, accounting for a quarter of all exports in 2011 (Fabling and Sanderson, 2008; www.statsnz.govt.nz; Vercoe, 2007).

Firm-level evidence suggests expansion beyond the small New Zealand market is a common driver of internationalisation regardless of sector (Skilling, 2001). Firms in the primary sector rely on location-bound natural resources coupled with innovation, tend to remain in the exporting phase, with some establishing their own export-supporting sales subsidiaries, but only the largest progressing to international sourcing and production (eg. Fonterra (diary), Zespri (kiwifruit), and Icebreaker (Merino wool), see Akoorie and Scott-Kennel, 2005; Mitchell, Smith, Dana, 2009; Dana and Schoeman, 2010). Many of the largest exporters have cooperative-based structures and some have traditionally enjoyed statutory rights as sole exporters in their respective industries on the justification that cooperation at home supports competitiveness abroad. Fonterra, for instance, is the largest dairy cooperative in control of 95 per cent of New Zealand total milk production, and accounting for 20 per cent New Zealand's total export receipts and 7 per cent of GDP (Dana and Schoeman, 2010: 74).

Manufacturers' modes are extremely varied, often beginning with simple exporting then moving to more alternative modes such as offshore sourcing and distribution that compliment highervalue added activities retained in New Zealand (Rochford, 2010; Dana and Dana, 2004; Dean et. 
al., 2000). Chetty and Campbell-Hunt (2004b) find in their study of 10 New Zealand manufacturers, they tend to adopt either a global approach defined by rapid internationalisation, specialised technology and a global market niche, or a regional approach focusing on diverse technologies and products for regional customers. Most, however, follow an incremental internationalisation path as knowledge of, and commitment to, international markets develops.

Service firms, by the nature of their offerings and the need to locate close to customers, often employ exporting in conjunction with network or partnership-based modes of entry. This may be achieved through temporary export of key personnel, or alliances for the duration of specific projects. Establishment of branch offices is less common. In many cases services are still provided from a New Zealand base, but marketing and customers are international (eg. education, tourism, IT services, consultancy). Diverse, although not always broad, choice of market scope and entry mode suggests service firms working closely with individual clients may more easily overcome cultural and institutional barriers (Coviello and Martin, 1999). Knowledge or innovation intensive SMEs, such as those in the services and high-technology sectors, are more likely to adopt emergent models of internationalisation (Bell et al., 2001a; Chetty and Stangl, 2010; Gerschewski, 2007).

\section{$5 \quad$ Method}

Literature on New Zealand firm internationalisation is characterised by plethora of case studies of individual, pairs or small groups of firms (Brydon and Dana, 2011; Akoorie and Scott-Kennel, 2005; Scott-Kennel and Akoorie, 2004; Campbell-Hunt et. al., 2001), complemented by handful of large scale surveys that provide more representative evidence (predominantly of SME exporters) (Akoorie and Enderwick, 1992; Alon et. al., 2009; Gerschewski, 2007). Thus, although our review enables us to identify dimensions of internationalisation models, discussed above, a more complete picture of which models are adopted by a cross-section of New Zealand firms is lacking. Thus, the purpose of the remainder of this paper is to present an historiographical examination of these dimensions of internationalisation models for multiple 
firms (Goodman and Kruger, 1988; O’Brien, Remenyi and Keaney, 2003; Yin, 1989). By taking this approach we hope to balance the richness of contextual, longitudinal data with a broad representation of a cross-section of New Zealand firms.

\subsection{Sample}

Evidence of internationalisation models was collected for thirty New Zealand firms involved in international activities. The final cases were selected from sixty potential cases, and care and effort was made to include not only those cases with the richest case material available, but also firms of different ages; sizes and from different industrial sectors, with different levels of international activity. To ensure sufficient background on each company prior to the cut off date of 2008, no company established after 2001 was selected. The oldest firm selected was established in 1868, with a total of four firms established pre-1900, seven between 1900 to 1950 , nine from 1951-1984 (when deregulation and liberalisation of the economy occurred), eight from 1985-2000 and two firms in 2001.

Size can be proxied by total revenue, sales or output, but as these figures are not widely available for all firms (particularly for privately owned firms), this study opted for the total number of employees worldwide (although most of the firms have the majority of their employees based in New Zealand). Thus, for the purposes of further investigation our cases are classified as follows: small (up to and including 50 employees worldwide), medium (up to and including 300 employees worldwide) and large (over 300 employees worldwide). The majority of New Zealand exports come from traditional sectors, with a high emphasis on primary, agricultural based food products (Bayfield et al., 2009). Firms were selected from the primary or natural resource-based sector (including processors of horticultural and agricultural products), manufacturing and tertiary sectors (firms primarily involved in the delivery of services or sales) (see Table 1a, in the results section, for frequencies by size and sector).

\subsection{Data collection}


Internationalisation histories for each of the firms were collated from the firms' inception until 2008, the cut-off point for our analysis. Data for all thirty firms was available through multiple sources, including published and non-published case studies or case histories in books, theses, government and industry websites and magazines; annual reports and websites of the individual firms themselves; and media. In most instances, the author also drew on information extracted from her own research and that of research students and colleagues that was specifically focused on the internationalisation of the case firms. This data included interviews conducted with individual firms and other data sources (ie. emails, archival documents, newsletters) used in the development of their internationalisation case histories (Akoorie and Scott-Kennel 2005).

This multiple source approach enabled the author to triangulate data to improve validity, reduce subjectivity, and construct a meaningful profile for each firm. Secondary sources were particularly useful for reconstruction of the early history of the firms as they do not have the

potential recall problems that can occur when asking about past events, retrospectively. For reasons of space, references to all material used for the purposes of profiling, such as short newspaper articles and websites for example, are omitted from the reference list, although references to key sources of material, in particular, those in the wider literature and books containing a number of case histories are included.

\subsection{Data analysis}

A content analysis approach was taken to analyse the data for each of the case study firms, and then across cases (Eisenhardt, 1989). The content analysis was directed by key characteristics of the firms namely their size and industry sector; and dimensions of international strategy as identified in the previous section, namely: international market scope; market entry modes and servicing strategies; timing and speed of internationalisation; and the barriers and drivers that influenced internationalisation. Data triangulation and reduction enabled key themes to emerge around these dimensions and the models of internationalisation. A comparative table including all firms is included in Appendix I, and the findings summarised in the following section. 


\section{$6 \quad$ Results}

The results section of this paper presents cross-case analysis by dimension (section 6.1), followed by discussion the internationalisation models emerging from our analysis (section 6.2). For more detail on each of the case firms, see Appendix I.

\subsection{Dimensions of Internationalisation}

Tables 1a and b present a summary of the data for each of the firms included in the sample by the internationalisation dimensions outlined in the literature review (namely; speed, market scope, entry and servicing modes), as well as distinguishing the firms by size and sector.

6.1.1 Timing \& Speed All but six firms in the sample adopted a gradual, incremental approach to internationalisation (see Table 1a). This involved development of the domestic market first - in some cases this remained the focus for most of the firms' history - followed by internationalisation into new and increasingly geographically and psychically distant markets over time. Firms with a rapid internationalisation path early in their lifecycle included a medium-sized manufacturer of wetsuits (Orca), and four small firms designing and marketing customised software. All these firms viewed innovation as one of the drivers or success factors behind their internationalisation. It was very clear that these firms were considerably younger than the others, with the oldest established in 1987, and four after 1995.

\section{*Table 1a about here*}

6.1.2 Market scope Analysis of the market scope of the sample revealed the geographical and socio-cultural patterns of international expansion of New Zealand firms. These fall into six different patterns which we refer to as: Local, characterised by firm activities solely in New Zealand and Australia; Top Four, where activities are centred on some or all of New Zealand's traditional and largest trading partners (Australia, UK, Japan and/or US) (note that although China is now New Zealand's second largest trading partner was not at the time of the study, and is included in the emergent category, next); Emergent where the firm has activities in 
any of the Local or Top Four markets as well as markets in Asia, South America or the Middle East; Niche - where a very narrow product range produced in Australasia and exported, sold, marketed and/or distributed by agents in a broad range of markets worldwide, in some instances with some support from the firm's sales team; Mass,; same as for Niche, but where the product range or market segments targeted are broader; and Global, which involves some manufacturing and sourcing activities outside of New Zealand coupled with an independently owned or operated sales and distribution presence in most countries. The frequencies of firms demonstrating these patterns of market scope are shown in Table $1 \mathrm{~b}$.

Cumulative market scope refers to the total market scope of the firm over its lifetime and enables us to see the extent to which each market grouping has been targeted by all firms. Current market scope is the total scope of international markets the firm is involved in when our data analysis ended (2008), and the frequencies by grouping are shown in Table 1b. Fletcher Building, a large construction firm, illustrates the difference between these two constructs. It first established itself in Australasia (Local) before moving into the Top Four markets, and finally internationalised its operations to Emergent markets in South America and India, thus would be included in all these categories under cumulative market scope. However, major debt and internal conflict within the firm caused it to divest its international operations, and to refocus on operations in local markets, thus its current (2008) market scope is classified as Local (further complicating this case is that since 2011 the firm has begun to re-internationalise but as this development is after 2008, we do not discuss this here or in the results).

*Table $1 b$ about here*

We find almost all firms started internationalising in Local (Australia) markets or one of the other Top Four markets. Further expansion is then directed into other Top Four markets, then Emergent markets (with both Asia and South America represented) or to Niche markets. The exceptions to this rule tend to be either large scale agricultural producers and primary processors that first exported to Mass markets (e.g. Fonterra (diary), Affco (meat), Zespri (kiwifruit), or small scale innovative firms either developing targeted products for global niche markets (e.g. 
Right Hemisphere, or taking advantage of specific opportunities that arose in Asia to internationalise first to emergent markets (e.g. AJ Park and TigerTurf).

Current market scope enables us to see the extent to which the firms are internationalised (in 2008). Somewhat surprisingly, given New Zealand firms' traditional reliance on culturally similar markets (i.e. Australia and the UK), over one third of the sample are operating in Emergent markets in wider Asia, South America and even the Middle East (the majority of this group also has a presence in Local and Top Four markets). Less surprising, but very promising, is the successful expansion into global niche markets by nearly a third of the sample. New Zealand's largest exporters of food and beverages were able to expand into Mass markets worldwide but only by using foreign agents and distributors. Of all the firms in our sample, only two really qualify as Global (Fonterra and Fisher \& Paykel) by having extensive offshore production and sales and marketing presence worldwide. The Local pattern of market scope is similarly sparsely populated by two firms, both having divested all international operations (The Warehouse, Fletcher Challenge) to return to a domestic focus.

6.1.3 Entry modes Our analysis found all market entry/servicing modes represented, but heavy reliance on exporting and investment (see Table 1b). Thus, the two core entry modes into foreign markets, are exporting either directly or indirectly on a regular basis (80 per cent of firms); and foreign direct investment (FDI) into a sales subsidiaries and/or production either via greenfield investment, acquisition of, or joint venture with, other company(s) (73 per cent). In addition to these core entry modes, firms employ complementary modes of entry either independently or in conjunction with the core modes, including: networks, alliances and partnerships (30 per cent) and contractual agreements such as licensing (10 per cent) and franchising ( 3 per cent). Finally, outsourcing of production offshore for the purposes of importing intermediate products, contract manufacturing (or marketing) and relocation of lower value added production activities, is a strategy used by 23 per cent of the firms. 
However, in contrast to evidence from the literature (which focuses on SMEs), only 20 per cent of the sample use exporting as their sole internationalisation mode (two thirds of these are smaller firms); and nearly three quarters of all firms engage in foreign direct investment. All types of investment modes of entry are apparent (i.e. merger, acquisition, greenfield and joint venture) with no particular differences by firm size or sector, however, the majority of firms establish their own offshore sales subsidiaries, some through acquisition of existing firms and assets. In addition, approximately two thirds of the firms are using different strategies simultaneously, for example exporting and investment into a sales subsidiary or formation of a network-based strategy. We find large and medium-sized firms more likely to engage in contractual, networking and investment-based strategies, primarily as a means to support exports and to better service international markets. Surprisingly, firms who internationalise using networks or alliances with overseas partners tend to be larger, rather than smaller, refuting the common perception that under-resourced, undercapitalised firms engage in networks more readily. In fact, many of the networks revealed by this analysis were for strategic rather than resource-seeking reasons.

\subsubsection{Drivers and constraints Drivers and constraints to internationalisation varied} considerably by firm. As there is considerable overlap between all these factors, Table 1c provides a summary indicating whether they had a favourable influence (e.g. positive drivers or success factors) or an unfavourable influence (e.g. negative factors that acted as drivers or constraints) on the firm's internationalisation. Further detail, by firm is summarised in Appendix I. The most commonly cited positive drivers to internationalisation are innovation and technology (43 per cent of the sample); networks, alliances and partnerships (27 per cent); and knowledge, skills and capabilities (20 per cent). Other favourable influences include marketingrelated elements of the firms' businesses (including (in order of frequency) marketing (13 per cent), brand/design (13 per cent), market opportunities (10 per cent), and market research (10 per cent). Specific firm capability influences include a niche focus (10 per cent), scale and/or scope (10 per cent), quality of inputs (7 per cent), and acquisitions ( 7 per cent). 
In contrast to the positive drivers of internationalisation which are almost all endogenous to the firms (with the exception of early government support and incentives mentioned by two older firms), almost all unfavourable or negative influences are exogenous. The most frequently mentioned are the small size of the New Zealand market (17 per cent of firms), foreign exchange rates (13 per cent), the costs of debt and doing business overseas (13 per cent), capital constraints (13 per cent), international competition (10 per cent) and trade restrictions and quotas (10 per cent). Other exogenous factors relate to removal of government support or incentives (6 per cent), market volatility and change (6 per cent). One firm's demise can be linked to endogenous factors but the author suspects that these factors, on the whole, were grossly underreported as reasons for failure internationally.

6.1.4 Size and sector Our final analysis considered whether our results were influenced by the size and sector of firms in the sample (frequencies are shown in Table 1a). Not unsurprisingly, we find large and medium-sized firms more likely to have implemented a broader range of entry mode strategies in a wider range of markets. Almost all of these firms still export, however. There are no small firms in mass or global markets, and just three from our sample are involved in foreign direct investment. Small firms, however, are more likely to face financial constraints, rapidly internationalise after inception and adopt a niche market strategy. Small and medium-sized firms are more likely have innovation as a driver for internationalisation than large firms.

In terms of sector, firms in natural resource-based sectors (including food processing and beverages, such as wine) tend rely almost totally on exporting to Mass markets from their New Zealand base, with the larger firms establishing offshore sales offices to support these activities. These firms found exchange rates and market volatility to be major constraints to internationalisation, and branding, marketing and marketing research important success factors. Drivers of internationalisation include increased capability (in production and human resources); improved product efficiency; increased overseas demand and globalisation of trade (which has prompted exporters to expand into growth markets in Asia); physical and psychic proximity to other markets (e.g. Australia); and a positive New Zealand image in offshore markets. 
In the manufacturing sector (excluding food processing/beverage), drivers to internationalisation include: the need for a global approach to business; increased opportunity to expand overseas and increased demand worldwide; and the simultaneous trends of export growth in New Zealand industry and low-cost outsourcing. After the mid-1990s, there was a trend towards outsourcing manufacturing but retaining product design and development in-house in New Zealand. In conjunction with this shift, many firms have adopted a global image and brand for strategic reasons which have furthered internationalisation efforts (i.e. Cavalier Bremworth, Peter Lynn Kites, and Pumpkin Patch).

Firms primarily engaged in the delivery of services or sales, demonstrate a greater likelihood of engagement in emerging markets and rely on business relationships and networks for success in foreign markets. The need for proximity to customers and focus on niche markets tend to drive internationalisation. Opportunities to export services to markets with high growth potential and to maintain business networks through increasingly sophisticated technologies are also driving internationalisation.

\subsection{Internationalisation models}

Our examination and analysis of the dimensions of internationalisation enables to define the model of internationalisation adopted by each firm. Most critical to determining the internationalisation model are the timing and speed of entry; the market scope which encompasses both diversity of market selection as well as the proximity (psychic or geographic) of early markets to New Zealand; and the range and resource intensity of entry modes chosen. Based on these dimensions, we find evidence of the traditional (stages) model, and of the emergent models of internationalisation, more specifically, 'born globals' and a type of 'born again global' firm. However, we also find firms that are not a natural fit with either of these models, and for reasons outlined below, refer to this group as 'transformational'. The remainder of the paper looks more closely at each of these groups of firms, using the dimensions of industry sector, firm size and internationalisation drivers and constraints to enrich our discussion. The 
model assigned to each firm is shown in the last column of the table in Appendix I, and frequencies are summarized in Table 2.

*Table 2 about here*

6.2.1 Traditional Of the 30 firms profiled over two thirds (21) follow (or followed) the traditional model of internationalisation (see Appendix 1, and Table 2). Of these, seven shifted to the transformational model during their lifecycle, these firms are discussed further below, and our focus here is on the remaining 14 firms. The most notable feature of this group is their focus on exporting and to a lesser extent, foreign direct investment in sales or production subsidiaries (sometimes with joint venture partners). Many of these firms, in line with the incremental or 'stages' model initiated internationalisation with low-risk/cost strategies (Johanson and Vahlne, 1977, see Deng et. al. 1995 for similar findings in the New Zealand context), but have not progressed to a heavy reliance on more resource-intense modes of internationalisation.

Two different types of firm can be identified within this rather truncated, traditional model. The first is the natural resource-based firm, characteristically large and with a long history of processing New Zealand's horticultural and agricultural outputs (eg. dairy, meat, kiwifruit) for export. Many of these firms evolved from state-owned enterprises or statutory marketing boards, or are anchored to the resource sectors either through their suppliers or buyers. Exports and investment are oriented to mass markets worldwide and in most instances are commodity products. Foreign direct investment in production and sales subsidiaries coupled with strategic alliances complements the basic exporting strategy for the larger firms. The traditional model of internationalisation demonstrated by these natural resource-based firms confirms the general findings of previous research.

The second type is the export-oriented firm which unlike the natural resource-based firm is not location bound, but still uses New Zealand (or a third country) as a base from which to export abroad. These firms include manufacturers of 'agri-tech' products, furniture, whiteware, carpet 
and clothing as well as service providers/manufacturers in construction, metal fabrication and agricultural retail supplies. The key driver to internationalisation of these firms is product or service innovation they can adapt to international markets. Manufacturers in this group are increasingly looking to offshore outsourcing to complement exporting and foreign investment activities by lowering the costs of production, while the construction, sales and service companies internationalising via sales subsidiaries to gain proximity to customers. Use of networks and alliances is very common amongst these firms. These findings are what we would expect of firms of this type, and suggest a flexible approach to internationalisation in response to the competitive pressures of the global business environment,

6.2.2 Emergent Our analysis of the speed, scope and entry modes of the firms suggests nine adopt an emergent model of internationalisation. All these firms are small to medium-sized and characterised by a reliance on international network relationships including alliances or outsourcing; innovation in the form of 'high-tech' product development or knowledge intensive services; and entry into psychically distant markets during the early phases of internationalisation. Brand, reputation, quality and market research are important success factors.

Six of the nine firms in this group are service firms, including five software firms and a law firm. The literature suggests such firms are likely to move to more advanced stages of internationalisation earlier than manufacturing or resource-based firms, often developing their own independent distribution channels to gain rapid proximity to customers in niche markets (Coviello and Martin, 1999; Scott-Kennel and von Batenburg, 2012). The adoption of the emergent model by this group of firms also appears to be connected with small market size, resource immobility, costs, and timing of internationalisation. A typical internationalisation path taken by this group would initially involve exporting the service in the form of overseas contract, and later form strategic alliances with foreign firms to either provide the service electronically often to niche market segments - from New Zealand or to establish a local sales subsidiary in the case of a need for market proximity. With respect to market selection, one trend apparent is that 
while service firms have typically targeted English-speaking countries, they are increasingly expanding into Asian markets due to abundant opportunities and potential for service firms.

Five of the firms included under the emergent model fit the notion of 'born global' - rapid internationalisation soon after establishment, followed by broad and diverse market scope and or market entry modes - and one firm (42Below) follows a similar pattern of internationalisation to the 'born again globals' identified by Bell et al. (2001a; b; 2003) - late, but rapid, internationalisation via exporting after exclusive focus on domestic markets. However, as takeover of this firm (constituting a 'critical incident') did not prompt internationalisation but instead lead to further internationalisation, we also include this firm under the transformation model, discussed below.

The remaining three firms are included in this group because of the similarities with "born global' and 'born again global' firms. These firms show similarities with 'born globals' in terms of their choice of markets and entry modes, however, internationalisation does not proceed with quite the rapidity of a typical 'born global' (Chetty and Campbell-Hunt, 2003b). Similarities also exist with 'born again globals', as internationalisation occurs later in life (Bell et. al., 2001b). Rather than a 'critical incident' such as a takeover or acquisition prompting the move to international markets, however, these firms internationalised on their own in response to opportunities arising in the business environment (e.g. the introduction of new IP law, demand for Astroturf in Asia for another, and relationships with market leaders for a third). What really distinguishes these firms as being emergent, however, is their choice of psychically distant emergent markets in Asia either as their first, or amongst the first markets for international entry. Frequently these firms employ more sophisticated and resource-intensive modes of entry, including networks, strategic alliances and sales subsidiaries in these markets. This internationalisation pattern sets them apart from firms following traditional or 'stages' models of internationalisation, as they 'leapfrog' the stages by focusing on advanced entry modes and emergent markets from the outset. 
6.2.3 Transformational Based on our analysis of the dimensions of internationalisation over time, we find more than one third of the firms (11) have deviated from traditional or emergent models of internationalisation following a major change or 'critical incident' that not fundamentally changes firm focus, resources, activities (and the scope, diversity, coordination and configuration of these resources and activities). We refer to this group as being 'transformational' to reflect how their activities and resources have been dramatically transformed.

For two of the transformational firms, the 'critical incident' was in the form of complete divestiture of all international activities and a re-focus on domestic operations, while the remaining nine firms experienced a change of ownership that accelerated and broadened the market scope of internationalisation. In the former case, divestment from international markets occurred due to inability to service them, manage international growth, poor returns (failure); internal conflict or debt. Whilst de-internationalisation or withdrawal from some international activities (Benito and Welch, 1997) is normal in the general scheme of things, and New Zealand firms in particular demonstrate intermittent exporting patterns, these two firms experienced insurmountable barriers (most likely compounded by international competition and a lack of international experience), forcing them to exit from what would were very costly forays abroad as both involved considerable foreign direct investment in the form of acquisitions.

With regard to the firms who experienced a change of ownership, eight were divested by their owners via a trade sale to a foreign-owned competitor in their industry, and one formed a strategic partnership (merger) with another New Zealand firm targeting similar markets. Almost all were privately owned and therefore not subject to hostile takeover. For the most part, these firms continue to operate from their New Zealand base whilst strengthening international connections (particularly market access and distribution). There is evidence of smaller, knowledge intensive firms (four in total, three of which are software) and also from traditional sectors (three). For the firms whose 'critical incident' was a trade sale to a competitor or related firm in their industry, there is parallel with the 'born again globals' described by Bell et. al. (2001a), with one important difference - all these firms demonstrated not only interest, but also 
active involvement, in internationalisation prior to the critical incident occurring (for similar findings see Scott-Kennel, forthcoming).

Indeed, international involvement is evident in all firms prior to transformation. Seven firms were following the traditional model, and four an emergent model of internationalisation (see Table 2, figures in parentheses). The traditional firms were either large (5) or medium-sized (2) engaged in food or beverage processing, construction and retail sectors, while emergent firms were medium-sized (1) or small (3), three producing and marketing software, and the fourth, a range of unique New Zealand vodkas. The characteristics of these four emergent firms are in line with those studied by Chetty and Campbell-Hunt (2004a), who find 'many attributes of the born-global model also characterize firms that began their internationalization along traditional lines but were radically transformed in the process of achieving global reach' (p.57).

To recap, firms following the transformational model are similar to so-called 'born-again globals' (Bell et. al., 2001a) with one important distinction. Born-again globals are domestically-focused firms that experience rapid internationalisation later, rather than earlier, in their life-cycle. This can also occur via trade sales to competitors. However, we find that, all the firms following the transformational model were already operating internationally - many for some time and very successfully - at the time of exit or trade sale. Indeed, evidence of either the traditional or emergent models of internationalisation is clearly evident well before the critical change occurred.

\section{Conclusions}

This study finds the focus of New Zealand firms is still in/direct exporting to psychically close countries. Initial forays abroad are typically directed to the country's top four trading partners (this differs slightly for service companies), and then to other markets. The literature suggests many firms remain solely as exporters rather than progressing to more resource intensive modes, but our research also finds evidence of frequent use of complementary modes, including foreign 
direct investment. Indeed, a large proportion of firms are very actively engaged in multiple internationalisation modes to support their exporting efforts.

The key driver of internationalisation is expansion beyond New Zealand's small market. Many firms, particularly smaller firms, rely heavily on market-led innovations for success in international markets. Barriers to internationalisation differ somewhat by size and experience, with smaller less-experienced firms citing finance as the most significant (see also Shaw and Darrock, 2004). Larger firms with more experience are more concerned with market access, organisational systems and managerial capabilities. As with previous research, this study finds metworks are key to facilitating internationalisation, particularly in the early stages, and appear to help circumvent both psychological and resource-based barriers (Coviello and Munro, 1995; Sadler and Chetty, 2010). Evidence of born (again) global firms and relocation and outsourcing of manufacturing activities suggests New Zealand firms are responding to global pressures by focussing on selected (niche) products and markets (Chetty and Campbell-Hunt, 2003b).

We find three types of internationalisation models adopted by New Zealand firms. There is substantial evidence of the traditional incremental or 'stages' model (Johanson and Valhne, 1977), although some firms remain permanently as exporters and do not advance readily through the stages (especially medium-sized manufacturers). These firms will continue to be plagued by costs associated with exchange rate fluctuations, transportation and insurance, if not able to disperse their activities more widely. However, our research also reveals these firms do engage in complementary international activities such as offshore manufacturing and outsourcing to meet such challenges head-on.

There is also evidence of the adoption of emergent models by firms that 'leapfrog' early stages of internationalisation by entering psychically distant markets via advanced entry modes from inception ('born globals) or internationalisation ('born again globals). This study found this pattern of internationalisation akin to 'born again globals' was more likely to be associated with opportunities in the international business environment presenting themselves and the firm's 
proactive response to such opportunities rather than a 'critical incident' such as a change of management or ownership as suggested by Bell et al. (2001a; 2003). In line with previous research, however, we find emergent firms include service firms and those rapidly internationalising on the basis of an innovation in product or process that has global appeal (Jones, 2001; Knight et. al., 2003). Scale and location in New Zealand is less of an issue for these firms than flexibility, focus and international credibility.

We also find evidence of a third group of firms exhibiting internationalisation paths characterised by change and transformation: either in ownership or exit from international markets. This model is characterised by an internationalisation path truncated or drastically altered in direction, scope or speed. Common to almost all of these firms is a focus on international markets prior to the change, which is in contrast to the 'born again globals' profiled in the work of Bell et. al. (2001a; b; and 2003), but similar to cases in Scott-Kennel (forthcoming). In most cases, the experiences of this outlier group are largely a result of the natural lifecycle of the firm in the global context of business, rather than a negative reflection of the inability of New Zealand firms to grow. As such, these firms serves to highlight the important and direct influence of the global international business environment on the activities of New Zealand firms.

These findings offer not only support but also challenge to the stages theory (Benito and Welch, 1997; Turnbull, 1987; Bell, 1995; Knight and Cavusgil, 1996; and Oviatt and McDougall, 1997). Our study builds on this stream of work by examining the internationalisation models of both small and large firms from a small open economy across sectors and longitudinally. Such an approach provides a broader perspective on internationalisation that has, hitherto, been narrowed by focus on small, new or innovative firms. Our findings suggest that transformation, particularly via trade sale, is increasingly common for internationalising firms from small open economies. This raises questions for future researchers regarding the impact of critical incidents on the transformation of firm's international trajectory in the longer term, and whether firms are able to persevere with independent internationalisation in the face of the barriers to global market opportunities. 


\section{References}

Agndal, H. and Chetty, S. (2007) 'The impact of relationships on changes in internationalisation strategies of SMEs', European Journal of Marketing, Vol. 41 No. 11/12), pp.1249-1474.

Akoorie, M. and Enderwick, P. (1992), The international operations of New Zealand companies', Asia Pacific Journal of Management, Vol. 9, pp. 99-117.

Akoorie, M. and Scott-Kennel, J. (2005) International Business Strategy: A New Zealand Perspective, Pearson Education, Auckland.

Alon, I., Dana, L-P. and Jenkins, A. (2009) 'International business by SMEs: Empirical evidence from New Zealand', Journal of International Business and Economy, Vol. 10 No. 2, pp. 59-78.

Andersen, O. (1993) 'On the internationalisation process of firms: A critical analysis', Journal of International Business Studies, Vol. 24, pp. 209-231.

Andrew Fletcher Consulting (2006) Report on Barriers to Export. Report prepared for New Zealand Trade and Enterprise, Wellington.

Bayfield, R., Dana, L.P. and Stewart, S. (2009) 'Firm characteristics and internationalisation strategies:an empirical investigation of New Zealand exporters', Int. J. Globalisation and Small Business, Vol. 3 No. 3, pp. 275-287.

Bell, J. (1995) 'The internationalization of small computer software firms: A further challenge to “stage” theories', European Journal of Marketing, Vol. 29 No. 8, pp. 60-75.

Bell, J., Young, S. and Crick, D. (1988) 'A holistic perspective on small firms internationalisation and growth', in Millar, C. C. and Choi, C. J. (Eds.). International Business and Emerging Markets, Vol. 1, pp. 9-29.

Bell, J., McNaughton, R., Young, S. and Crick, D. (2001a) 'Towards an eclectic model of small firm internationalisation', in Proceedings of the $4^{\text {th }}$ McGill Conference on International Entrepreneurship, University of Strathclyde, Glasgow, Vol. 1, pp. 95-110.

Bell, J., McNaughton, R. and Young, S. (2001b) 'Born-again global' firms: an extension to the 'born global' phenomenon', Journal of International Management, Vol. 7 No. 3, pp. 173-189.

Bell, J., McNaughton, R., Young, S. and Crick, D. (2003) 'Towards an integrative model of small firm internationalisation', Journal of International Entrepreneurship, Vol. 1 No. 4, pp. 339-362.

Benito, G. R. G. and Welch, L. S. (1997) 'De-internationalization', Management International Review, Vol. 37, No. 2, pp. 7-25. 
Berg, J. N., and R. T. Hamilton. (1998) 'Born to fail? International strategic alliances experiences of New Zealand companies', Journal of International Business \& Entrepreneurship, Vol. 6 Nos. 1 \& 2, pp. 63-76.

Bollard, A. E. and Cremer, R.D. (1999) Succeeding in the World Economy: New Zealand Outward Direct Investment, Dunmore Press Limited, Palmerston North.

Bowen, E., Haworth, N; and Wilson, H. (2003) 'Encouraging more SMEs to take their big OE', University of Auckland Business Review, Vol. 5 No. 2, pp. 2-10.

Brydon, K. and Dana, L-P. (2011) 'Globalisation and firm structure: comparing a family business and a corporate block holder in the New Zealand seafood industry', Int. J. Globalisation and Small Business, Vol. 4 No. 2, pp. 206-220.

Buckley, P. J. and Casson, M. A. (1993) 'Theory of international operations', in Buckley, P. J. and Ghauri, P. (Eds.), The Internationalisation of the Firm: A Reader. Academic Press Ltd, London, pp. 45-50.

Campbell-Hunt, C., Brocklesby, J., Chetty, S., Corbett, L., Davenport, S., Jones, D.; and Walsh P. (2001) World Famous in New Zealand: How New Zealand's Leading Firms Became WorldClass Competitors, Auckland University Press, Auckland.

Castalia Strategic Advisors (2007) Successful Models for New Zealand Export Businesses. A Report for the New Zealand Treasury, Wellington.

Caughey, M. and Chetty, S. (1994) 'Pre-export behaviour of small manufacturing firms in New Zealand', International Small Business Journal, Vol. 12 No. 3, pp. 62-68.

Chetty, S. (1994) 'Business networks as a determinant of export performance', Journal of International Marketing, Vol. 2 No. 4, pp. 11-15.

Chetty, S. K. (1999) 'Dimensions of internationalisation of firms in the apparel industry', European Journal of Marketing, Vol. 33 No. 1/2, pp. 121-142.

Chetty, S. K. and Blankenburg Holm, D. B. (2000) 'Internationalisation of small to mediumsized manufacturing firms: A network approach', International Business Review, Vol. 9, pp. 7793.

Chetty, S. K. and Campbell-Hunt, C. (2003a) 'Paths to internationalisation among small- to medium-sized firms: A global versus regional approach', European Journal of Marketing, Vol. 37 No. 5/6, pp. 796-820.

Chetty, S. K. and Campbell-Hunt, C. (2003b) 'Explosive international growth and problems of success amongst small to medium-sized firms', International Small Business Journal, Vol. 21 No. 1, pp. 5-27. 
Chetty, S. K. and Campbell, C. (2004a) 'A strategic approach to internationalization: A traditional versus a "born-global" approach. Journal of International Marketing, Vol. 12 No. 1, pp. 57-81.

Chetty, S. K. and Campbell-Hunt, C. (2004b) 'Internationalisation strategy and its impact on learning during the process', Journal of Asia Pacific Marketing, Vol. 3 No. 2, pp. 38-52.

Chetty, S. K. and Stangl, L. M. (2010) 'Internationalization and innovation in a network relationship context', European Journal of Marketing, Vol. 44, No. 11/12, pp. 1725-1743.

Chetty, S.K. and Wilson, H. M.(2003) 'Collaborating with competitors to acquire resources', International Business Review, Vol. 12, pp. 61-81.

Cooling, D. (1995) New Zealand outward foreign direct investment: Analysis of patterns from company data. Outward Direct Investment Report No. 4, Working Paper 95/32. New Zealand Institute for Economic Research, Wellington.

Coviello, N. E. and Martin, K. A-M. (1999) 'Internationalization of service SMEs: An integrated perspective from the engineering consulting sector', Journal of International Marketing, Vol. 7, No. 4, pp. 42-66.

Coviello, N.E. and McAuley, A. (1999) 'Internationalisation and the smaller firm: A review of contemporary empirical research', Management International Review, Vol. 39 No. 3, pp. 223257.

Coviello, N. E. and Munro, H. (1995) 'Growing the entrepreneurial firm: Networking for international market development’, European Journal of Marketing, Vol. 29, No. 7, pp. 49-61.

Coviello, N. E. and Munro, H. (1997) 'Network relationships and the internationalisation process of small software firms', International Business Review, Vol. 6 No. 4, pp. 361-386.

Dana, L. P. and Dana, T. E. (2004) 'On the internationalisation of New Zealand SMEs', Int. J. Entrepreneurship and Small Business, Vol. 1 No. 3/4, pp. 330-338.

Dana, L.P., Grimwood, S. and William, G. (2009) 'Export incentives and international entrepreneurship in New Zealand firms', Journal for International Business and Entrepreneurship Development, Vol. 4 No. 1/2, pp. 1-21.

Dana, L. P., Hamilton, R. T. and Pauwels, B. (2007) 'Evaluating offshore and domestic production in the apparel industry: The small firm's perspective', Journal of International Entrepreneurship, Vol. 5, pp. 47-63.

Dana, L. P. and Schoeman, J. (2010) ‘An entrepreneurial innovation: Mega cooperatives', AsiaPacific Journal of Innovation and Entrepreneurship, Vol. 4 No. 1, pp. 67-88. 
Davenport, S. (2009) Where does International Entrepreneurship End? Exploring Entrepreneurial Exist from Internationalised SMES through Trade Sales, Victoria Management School Working Paper Series 01-09, Victoria University of Wellington, Wellington.

Deloitte (2008) Net Economic Benefit from Outward Direct Investment, Report prepared for New Zealand Trade and Enterprise, Wellington.

Dean, D.L., Mengüç, B. and Myers, C.P. (2000) 'Revisiting firm characteristics, strategy, and export performance relationship: a survey of the literature and an investigation of New Zealand small manufacturing firms', Industrial Marketing Management, Vol. 29 No. 5, pp. 461-477.

Deng, S., Duffy, M. F. and Harrison, R. (1995) 'Internationalization in small, commodity based economies: The New Zealand example', Asia Pacific Journal of Marketing and Logistics, Vol. 7 No. 1/2, pp. 37-61.

Dunning, J. H. (1981) International Production and the Multinational Enterprise, Allen \& Unwin, London.

Eisenhardt, K. M. (1989) 'Building theories from case study research', Academy of Management Review, Vol. 14 No. 4, pp. 532-550.

Enderwick, P. and Ronayne, E. (2004) 'Reconciling entrepreneurship and organisational structure in international operations: Evidence from New Zealand specialist food exporters', Journal of Asia Pacific Marketing, Vol. 3 No. 2, pp. 53-68.

Enderwick, P. and Scott-Kennel, J. (2009) 'New Zealand and the challenge of global competition', in Van Den Bulcke, D., Verbeke, A. and Yuan, W. (Eds.), Handbook on Small Nations in the Global Economy: The Contribution of Multinational Enterprises to National Economic Success, Edward Elgar, Cheltenham, UK, pp. 219-243.

Etemad, H. (2004) 'Marshalling relations: The enduring essence of international entrepreneurship', in Dana, L.-P., (Ed.), Handbook of International Enterpreneurship, Edward Elgar, Cheltenham, UK, pp.

Etemad, H. (2009) 'Internationalization of small and medium sized enterprises: A grounded theoretical framework and an overview', Canadian Journal of Administrative Sciences, Vol. 21 No. 1, pp. 1-21.

Etemad, H. and Wright, G. (2003) 'Internationalization of SMEs: Towards a new paradigm', Introduction to a Special Issue of Small Business Economics, Vol. 20, pp. 1-4.

Fabling, R., Grimes, A., Sanderson L. and Stevens, P. (2008) Some rise by sin, and some by virtue fall: Firm dynamics, market structure and performance, Ministry of Economic Development Occasional Paper 08/10, Wellington. 
Fabling, R. and Sanderson, L. (2007) 'Peter Piper picked a peck of pickled peppers and packed them off to Portugal: firm level patterns in merchandise trade', New Zealand Association of Economists Annual Conference, Christchurch.

Gawith, A. (2002) Firm-level Manufacturing Export Study, A report for the Ministry of Economic Development, The Treasury and Trade New Zealand, Infometrics Ltd, Wellington.

Gerschewski, S. (2007) Understanding pre-export behaviour of small and medium-sized firms in New Zealand: Towards a model of export readiness, Unpublished Masters Thesis, Victoria University of Wellington, Wellington.

Goodman, R. S. and Kruger, E. J. (1988) 'Data dredging or legitimate research method? Historiography and its potential for management research, Academy of Management Review, Vol.13 No. 2, pp. 315-325

Hadleigh, D. (2005) Resource Based Theory of Internationalisation - Evidence from New Zealand, Unpublished Masters Thesis, University of Otago, Otago.

Hamilton, R. T. and Chow, Y. K. (1993) 'Why managers divest - evidence from New Zealand's largest companies', Strategic Management Journal, Vol. 14 No. 6, pp. 479-484.

Hamilton, R. T. and Dana, L. P. (2003) 'An increasing role for small business in New Zealand', Journal of Small Business Management, Vol. 41 No. 4, pp. 402-408.

Infometrics. (1999) Firm-level Export Study Trends and Issues A report for The Treasury, Infometrics Ltd, Wellington.

Jaeger, S., and Rudzki, R. (2007) 'How SMEs engage in the global economy - cases from New Zealand', Oxford Business \& Economics Conference, Oxford.

Johanson, J. and Vahlne, J.-E. (1977) 'The internationalisation process of the firm: A model of knowledge development and increasing foreign market commitments', Journal of International Business Studies, Vol. 8 No. 1, pp. 23-32.

Johanson, J. and Wiedersheim-Paul, F. (1975) 'The internationalization of the firm - four Swedish cases', Journal of Management Studies, Vol. 12 No. 3, pp. 305-323.

Jones, M. V. (1999) 'The internationalization of high-technology firms', Journal of International Marketing, Vol. 7 No. 4, pp. 15-41.

Jones, M. V. (2001) 'First steps in internationalisation: Concepts and evidence from a sample of small high-technology firms', Journal of International Management, Vol. 7 No. 3, pp. 191-210.

Kingshott, R. P. J. and Pickering, P. (2005) 'The internationalisation strategy of the New Zealand VSE: A social exchange relationship building perspective', Journal of Asia Pacific Marketing, Vol. 4 No. 1, pp. 53-75. 
Knight, J., Bell, J. and McNaughton, R. (2003) 'Born globals: Old wine in new bottles?', ANZMAC Conference Proceedings: Bridging Marketing Theory and Practice, Auckland.

Knight, G. A., and Cavusgil, S. T., (1996) 'The Born Global firm: A challenge to traditional internationalization theory', Advances in International Marketing, Vol. 8, pp. 11-26.

Knight, G.A., and Cavusgil, S.T. (2004) 'Innovation, organizational capabilities, and the bornglobal firm', Journal of International Business Studies, Vol. 35 No. 2, pp. 124-141.

Leonidou, L. C. and Katsikeas, C. S. (1996) 'The export development process: An integrative review of empirical models', Journal of International Business Studies, Vol. 27 No. 3, pp. 51751.

Loane, S. and Bell, J. (2006) 'Rapid internationalisation among entrepreneurial firms in Australia, Canada, Ireland and New Zealand: An extension to the network approach', International Marketing Review, Vol. 23 No. 5, pp. 467-485.

Loane, S., Bell, J.D. and McNaughton, R. (2007) 'A cross-national study on the impact of management teams on the rapid internationalization of small firms', Journal of World Business, Vol. 42, pp. 489-504.

Luostarinen, R. (1980) Internationalisation of the Firm. Acta Academic Oeconomica Helsingiensis, The Helsinki School of Economics, Helsinki.

Miesenbock, K. J. (1988) 'Small business and exporting: A literature review', International Small Business Journal, Vol. 6, No. 2, pp. 42-61.

McKee, J. (2003) 'Capital markets for small and medium enterprises: An evaluation of recent New Zealand Experience', The 2nd Annual Conference of PECC Finance Forum, Hua Hin, Thailand.

MED (2007) Firm Capability Team Industry and Regional Development Branch, Ministry of Economic Development, Wellington.

Mitchell, J. D., Smith, L. J. and Dana, L.-P. (2009) 'The international marketing of New Zealand merino wool: past, present and future', Int. J. Business and Globalisation, Vol. 3 No. 2, pp. 111122.

Nees, C. and Nixon, C. (2005) Trade, Growth and Global Connectivity in the New Zealand context, NZ Trade Consortium Working Paper no. 34, New Zealand Institute of Economic Research, Wellington.

O’Brien, J., Remenyi, D. and Keaney, A. (2003) 'Historiography - A neglected research method in business and management studies', E-Journal of Business Research Methods, Vol. 2 No. 2, pp. 135-143. 
OECD/APEC (2006) 'OCED-APEC Keynote Paper on Removing Barriers to SME Access to International Markets', OECD-APEC Global Conference, Athens, Greece.

Oesterle, M. J. (1997) 'Time span until internationalization: Foreign market entry as a built-in mechanism of innovations', Management International Review, Vol. 37 No. 2, pp. 125-149.

Oviatt, B. M. and McDougall, P. P. (1994) 'Towards and theory of international new ventures', Journal of International Business Studies, Vol. 25 No. 1, pp. 45-64.

Oviatt, B. M. and McDougall, P. P. (1995) 'Global start-ups: Entrepreneurs on a worldwide stage. Academy of Management Executive’, Vol. 9 No. 2, pp. 30-43.

Oviatt, B. M. and McDougall, P. P. (1997) 'Challenges for internationalization process theory: The case of international new ventures', Management International Review, Vol. 37 (special issue), pp. 85-99.

Rialp, A., Rialp, J. and Knight, G. A. (2005) 'The phenomenon of early internationalizing firms: What do we know after a decade (1993-2003) of scientific inquiry?', International Business Review, Vol. 14 No. 2, pp. 147-166.

Rochford, K. (2010) 'Those who stayed loyal. An empirical examination of New Zealand manufacturers surviving in a global market', Journal of Enterprising Communities: People and Places in the Global Economy, Vol. 4 No. 4, pp. 346-371.

Sadler, A. and Chetty, S. (2000) 'The impact of networks on New Zealand firms', in Dana, L-P., (Ed.), Global Marketing and Co-operation and Networks, Haworth Press, New York.

Scott-Kennel, J. (2008) Internationalisation of New Zealand firms: Drivers, constraints and business models, Report prepared for the Ministry of Economic Development, Wellington.

Scott-Kennel, J. (forthcoming) 'Selling to Foreign MNEs: End of the Road or the Beginning of a Journey for Firms from Small Advanced Economies?', International Studies of Management and Organization.

Scott-Kennel, J. and Akoorie, M. (2004) 'Cycling in tandem: An exploratory study of MNE and SME integration, Int. J. of Entrepreneurship and Small Business, Vol. 1 No. 3/4, pp. 339-362.

Scott-Kennel, J. and von Batenburg, Z. (2012) 'The role of knowledge and learning in the internationalisation of professional service firms', The Services Industry Journal, Vol. 32 No. 10, pp.1667-1690.

Shaw, V. and Darrock, J. (2004) 'Barriers to internationalisation: A study of entrepreneurial new ventures in New Zealand', Journal of International Entrepreneurship, Vol. 2, pp. 327-343. 
Simmons, G. (2002) Growing pains: New Zealand Qualitative Evidence on Hurdles to Exporting Growth, New Zealand Treasury Working Paper 02/10, Wellington.

Skilling, D. (2001) The Importance of being Enormous: Toward an Understanding of the New Zealand Economy, The New Zealand Treasury, Wellington.

Skilling, D. and Boven, D. (2006) The flight of the Kiwi: Going global from the end of the world, The New Zealand Institute Discussion Paper 2006/1, Wellington.

Sweet, A. and Nash, M. (2007) Firms' Decisions on the Location of Economic Activity - A Survey, Report for the New Zealand Treasury, Wellington.

Taylor, M. and Jack, R. (2011) 'Understanding the pace, scale and pattern of firm internationalization: An extension of the 'born global' concept', International Small Business Journal, Vol. 0 No. 0, pp. 1-21.

Turnbull, P. W. (1987) 'A challenge to the stages theory of the internationalisation process', in Rosson, P. J. and Reid, S. D. (Eds.), Managing Export Entry and Expansion, Praeger, New York, pp. 21-40.

Vercoe, A. (2007) New Zealand's export profile - By level of processing. Ministry of Foreign Affairs and Trade Research Note, Wellington.

Welch, L. S. and Luostarinen, R. (1988) 'Internationalisation: Evolution of a concept', Journal of General Management, Vol. 14 No. 2, pp. 34-55.

Wright, R. W. and Dana, L.-P. (2003) 'Changing paradigms of international entrepreneurship strategy’, Journal of International Entrepreneurship, Vol. 1, pp. 135-152.

Yin, R. K. 2003. Case Study Research: Design and Methods, ( ${ }^{\text {rd }}$ ed.), Sage, Thousand Oaks, CA. 


\section{Appendix I New Zealand Firm Internationalisation Dimensions*}

\begin{tabular}{|c|c|c|c|c|c|c|}
\hline $\begin{array}{l}\text { Operating Name(s) } \\
\text { (establishment date) }\end{array}$ & $\begin{array}{l}\text { Size } \\
\text { Sector }\end{array}$ & Speed & $\begin{array}{l}\text { Market } \\
\text { Scope }\end{array}$ & $\begin{array}{l}\text { Market Entry / } \\
\text { Servicing Modes }\end{array}$ & $\begin{array}{l}\text { Drivers \& } \\
\text { Constraints }^{\wedge}\end{array}$ & Model \\
\hline $\begin{array}{l}\text { NZ Dairy Marketing Board } \\
\text { (1961) } \\
\text { Fonterra Dairy (2001) }\end{array}$ & $\begin{array}{l}\text { Large } \\
\text { Primary } \\
\text { (dairy) }\end{array}$ & Slow & $\begin{array}{l}\text { Mass } \\
\text { Global }\end{array}$ & $\begin{array}{l}\text { Exporting } \\
\text { Investment (sales subs, JV) } \\
\text { Network (strategic alliance) }\end{array}$ & $\begin{array}{l}\text { +Scale \& scope } \\
\text { +Marketing } \\
\text { +Global Industry } \\
\text { + Int. experience }\end{array}$ & Traditional \\
\hline $\begin{array}{l}\text { Watties (1934) } \\
\text { Goodman Fielder Wattie (1987) } \\
\text { HeinzWatties (1992) }\end{array}$ & $\begin{array}{l}\text { Large } \\
\text { Primary } \\
\text { (processor) }\end{array}$ & Slow & $\begin{array}{l}\text { Local } \\
\text { Top } 4\end{array}$ & Exporting & $\begin{array}{l}\text {-Trade restrictions } \\
+ \text { Market opportunities } \\
+ \text { Brand }\end{array}$ & $\begin{array}{l}\text { Traditional then } \\
\text { Transformational } \\
\text { (trade sale) }\end{array}$ \\
\hline $\begin{array}{l}\text { Montana Wines (1934) } \\
\text { Pernod Ricard NZ Ltd }\end{array}$ & $\begin{array}{l}\text { Large } \\
\text { Primary } \\
\text { (winery) }\end{array}$ & Slow & $\begin{array}{l}\text { Local } \\
\text { Mass }\end{array}$ & $\begin{array}{l}\text { Exporting } \\
\text { Investment (sales subsidiary) } \\
\text { Network (strategic alliances) }\end{array}$ & $\begin{array}{l}\text { +Reputation } \\
\text { +Market research } \\
\text { +Networks } \\
\text { +Government support } \\
\text { +NZ image }\end{array}$ & $\begin{array}{l}\text { Traditional then } \\
\text { Transformational } \\
\text { (takeover, trade sale) }\end{array}$ \\
\hline $\begin{array}{l}\text { Fisher \& Paykel (Whiteware) } \\
\text { (1934) }\end{array}$ & $\begin{array}{l}\text { Large } \\
\text { Secondary } \\
\text { (manufacture) }\end{array}$ & Slow & $\begin{array}{l}\text { Top } 4 \\
\text { Global }\end{array}$ & $\begin{array}{l}\text { Exporting } \\
\text { Investment (production) } \\
\text { Network (strategic alliance) } \\
\text { Outsourcing }\end{array}$ & $\begin{array}{l}\text {-Small NZ market } \\
\text {-Forex } \\
\text { +Innovation (patents) }\end{array}$ & Traditional \\
\hline $\begin{array}{l}\text { Fletcher Construction (1919) } \\
\text { Fletcher Challenge (1981) } \\
\text { Fletcher Building (2000) } \\
\text { *Re-internationalisation } 2011\end{array}$ & $\begin{array}{l}\text { Large } \\
\text { Secondary } \\
\text { (construction) }\end{array}$ & Slow & $\begin{array}{l}\text { Local } \\
\text { Top } 4 \\
\text { Emergent } \\
\text { (S.A, India) } \\
\end{array}$ & $\begin{array}{l}\text { Investment } \\
\text { (strategic acquisitions) } \\
\text { Networks }\end{array}$ & $\begin{array}{l}\text { +Acquisitions } \\
\text {-Debt } \\
\text {-Management practices } \\
\text {-Internal conflict }\end{array}$ & $\begin{array}{l}\text { Traditional then } \\
\text { Transformational } \\
\text { (international } \\
\text { divestiture) } \\
\end{array}$ \\
\hline Gallagher Group (1938) & $\begin{array}{l}\text { Large } \\
\text { Secondary } \\
\text { (manufacture) }\end{array}$ & Slow & $\begin{array}{l}\text { Top } 4 \\
\text { Emergent } \\
\text { (Asia, S.A.) }\end{array}$ & $\begin{array}{l}\text { Exporting } \\
\text { Investment (sales subsidiaries, } \\
\text { Joint Ventures) }\end{array}$ & $\begin{array}{l}+ \text { Govt. incentives for } \\
\text { exporting } \\
\text {-removal of incentives } \\
+ \text { Networks } \\
+ \text { Knowledge }\end{array}$ & Traditional \\
\hline $\begin{array}{l}\text { Bremworth Carpet (1959) } \\
\text { Cavalier Corp (1991) }\end{array}$ & $\begin{array}{l}\text { Large } \\
\text { Secondary } \\
\text { (manufacture) }\end{array}$ & Slow & $\begin{array}{l}\text { Local } \\
\text { Mass }\end{array}$ & $\begin{array}{l}\text { Exporting } \\
\text { Investment (acquisition, sales } \\
\text { subsidiaries, production) } \\
\text { Outsourcing } \\
\end{array}$ & $\begin{array}{l}\text {-Exchange rates } \\
\text {-Small NZ market } \\
\text { +Financial strength } \\
\text { +Quality input }\end{array}$ & Traditional \\
\hline $\begin{array}{l}\text { Wright Stephenson \& Co. (1868) } \\
\text { Wrightson Ltd (1993) } \\
\text { PGG Wrightson (2005) }\end{array}$ & $\begin{array}{l}\text { Large } \\
\text { Tertiary } \\
\text { (retail) }\end{array}$ & Slow & $\begin{array}{l}\text { Local } \\
\text { Emergent } \\
\text { (S.A.) }\end{array}$ & $\begin{array}{l}\text { Network (strategic alliance) } \\
\text { Investment (sales subsidiaries, } \\
\text { mergers) }\end{array}$ & $\begin{array}{l}\text {-Market volatility } \\
+ \text { Alliances }\end{array}$ & Traditional \\
\hline $\begin{array}{l}\text { Min. Works \& Devl. (1870) } \\
\text { Works \& Dev. Services (1988) } \\
\text { OPUS Int. Consultants (1997) }\end{array}$ & $\begin{array}{l}\text { Large } \\
\text { Tertiary } \\
\text { (construction) }\end{array}$ & Slow & $\begin{array}{l}\text { Top } 4 \\
\text { (UK, N.A) } \\
\text { Australia } \\
\end{array}$ & $\begin{array}{l}\text { Exporting } \\
\text { Investment (sales subsidiaries, } \\
\text { acquisitions, mergers) }\end{array}$ & +Skills, capability & $\begin{array}{l}\text { Traditional then } \\
\text { Transformational } \\
\text { (trade sale) }\end{array}$ \\
\hline The Warehouse (1982) & $\begin{array}{l}\text { Large } \\
\text { Tertiary } \\
\text { (retail) }\end{array}$ & Slow & Local & Investment (Acquisition) & $\begin{array}{l}\text { +Infrastructure } \\
\text {-Competition }\end{array}$ & $\begin{array}{l}\text { Traditional } \\
\text { Transformational } \\
\text { (international } \\
\text { divestiture) } \\
\end{array}$ \\
\hline Pumpkin Patch (1990) & $\begin{array}{l}\text { Large } \\
\text { Tertiary } \\
\text { (retail) }\end{array}$ & Slow & $\begin{array}{l}\text { Local } \\
\text { Top } 4 \\
\text { Emergent } \\
\text { (Asia, M.E.) }\end{array}$ & $\begin{array}{l}\text { Exporting (direct) } \\
\text { Investment (sales subsidiaries) } \\
\text { Licensing } \\
\text { Outsourcing }\end{array}$ & $\begin{array}{l}\text {-quotas } \\
\text {-interest costs } \\
\text { +Brand \& design } \\
\text { +Supplier relationships } \\
\text { +Use of technology }\end{array}$ & Traditional \\
\hline AFFCO (1904) & $\begin{array}{l}\text { Medium } \\
\text { Primary } \\
\text { (processor) }\end{array}$ & Slow & Mass & $\begin{array}{l}\text { Exporting } \\
\text { Investment (acquisition, sales } \\
\text { subsidiaries) }\end{array}$ & $\begin{array}{l}\text {-exchange rates } \\
\text { +Quality and in-time } \\
\text { supply }\end{array}$ & Traditional \\
\hline Nobilo Wines (1943) & $\begin{array}{l}\text { Medium } \\
\text { Primary } \\
\text { (winery) }\end{array}$ & Slow & Top 4 & $\begin{array}{l}\text { Exporting } \\
\text { Investment (JV, sales) }\end{array}$ & $\begin{array}{l}\text { +Network with } \\
\text { distribution channel } \\
\text { partners }\end{array}$ & $\begin{array}{l}\text { Traditional then } \\
\text { Transformational } \\
\text { (trade sale) }\end{array}$ \\
\hline $\begin{array}{l}\text { NZ Kiwifruit Authority (1977) } \\
\text { NZ Kiwifruit Marketing Board } \\
(1988) \\
\text { Zespri (2000) }\end{array}$ & $\begin{array}{l}\text { Medium } \\
\text { Primary } \\
\text { (fruit export) }\end{array}$ & Slow & Mass & $\begin{array}{l}\text { Exporting } \\
\text { Investment (sales subsidiary) } \\
\text { Outsourcing partnerships } \\
\text { Licensing }\end{array}$ & $\begin{array}{l}\text { +Brand } \\
\text { +Innovation } \\
\text { +Managerial expertise } \\
\text {-Brand protection } \\
\text {-Limited capital }\end{array}$ & Traditional \\
\hline NDA Engineering (1894) & $\begin{array}{l}\text { Medium } \\
\text { Secondary } \\
\text { (manufacture) }\end{array}$ & Slow & $\begin{array}{l}\text { Local } \\
\text { Top } 4 \\
\text { Emergent } \\
\text { (China) } \\
\text { Niche }\end{array}$ & $\begin{array}{l}\text { Exporting } \\
\text { Network (strategic alliance) } \\
\text { Investment (production) }\end{array}$ & $\begin{array}{l}\text { +Capability \& } \\
\text { innovation }\end{array}$ & Traditional \\
\hline
\end{tabular}




\begin{tabular}{|c|c|c|c|c|c|c|}
\hline $\begin{array}{l}\text { Operating Name(s) } \\
\text { (establishment date) }\end{array}$ & $\begin{array}{l}\text { Size } \\
\text { Sector }\end{array}$ & Speed & $\begin{array}{l}\text { Market } \\
\text { Scope }\end{array}$ & $\begin{array}{l}\text { Market Entry / } \\
\text { Servicing Modes }\end{array}$ & $\begin{array}{l}\text { Drivers \& } \\
\text { Constraints }^{\wedge}\end{array}$ & Model \\
\hline $\begin{array}{l}\text { Formway Furniture } \\
\text { (1955) }\end{array}$ & $\begin{array}{l}\text { Medium } \\
\text { Secondary } \\
\text { (manufacture) }\end{array}$ & Slow & $\begin{array}{l}\text { Local } \\
\text { Niche }\end{array}$ & $\begin{array}{l}\text { Exporting } \\
\text { Investment (sales/prod.) } \\
\text { Licensing }\end{array}$ & $\begin{array}{l}\text { +Innovation } \\
\text { +Scale }\end{array}$ & Traditional \\
\hline Orca (1992) & $\begin{array}{l}\text { Medium } \\
\text { Secondary } \\
\text { (manufacture) }\end{array}$ & Rapid & $\begin{array}{l}\text { Local } \\
\text { Niche }\end{array}$ & $\begin{array}{l}\text { Exporting } \\
\text { Outsourcing } \\
\text { Investment (production) }\end{array}$ & $\begin{array}{l}\text { +Innovation (R\&D) } \\
\text { +Marketing } \\
\text { +Reputation }\end{array}$ & $\begin{array}{l}\text { Emergent } \\
\text { (born global) }\end{array}$ \\
\hline $\begin{array}{l}\text { Criterion Furniture } \\
(1970) \\
\text { *in receivership Feb } \\
2012\end{array}$ & $\begin{array}{l}\text { Medium } \\
\text { Secondary } \\
\text { (manufacture) }\end{array}$ & Slow & $\begin{array}{l}\text { Local } \\
\text { Top } 4 \\
\text { Emergent } \\
\text { (Asia, S.A., } \\
\text { M.E.) }\end{array}$ & $\begin{array}{l}\text { Exporting } \\
\text { Outsourcing }\end{array}$ & $\begin{array}{l}\text {-transaction costs } \\
\text {-overseas competitor } \\
\text {-Export incentives } \\
\text {-maturing market } \\
\text { +production capacity } \\
\text { +Innovation, marketing }\end{array}$ & Traditional \\
\hline AJ Park (1891) & $\begin{array}{l}\text { Medium } \\
\text { Tertiary } \\
\text { (law consult) }\end{array}$ & $\begin{array}{l}\text { Slow } \\
\text { (late) }\end{array}$ & $\begin{array}{l}\text { Emergent } \\
\text { (HK, Asia) }\end{array}$ & Network (alliance) & $\begin{array}{l}\text { +development of IP } \\
\text { law, increasing } \\
\text { demand for services } \\
+ \text { intellectual property }\end{array}$ & $\begin{array}{l}\text { Emergent } \\
\text { (born again global, } \\
\text { diverse markets, } \\
\text { networks) }\end{array}$ \\
\hline $\begin{array}{l}\text { Software of Excellence } \\
\text { (1987) } \\
\text { (acquired byHenry } \\
\text { Schein (US) in } 2007 \& \\
\text { delisted) }\end{array}$ & $\begin{array}{l}\text { Medium } \\
\text { Tertiary } \\
\text { (software) }\end{array}$ & Rapid & $\begin{array}{l}\text { Local } \\
\text { Top } 4 \\
\text { Emergent } \\
\text { (Middle } \\
\text { East) }\end{array}$ & $\begin{array}{l}\text { Exporting } \\
\text { Investment (sales } \\
\text { subsidiaries, acquisition) }\end{array}$ & $\begin{array}{l}\text {-Small NZ market } \\
\text {-Overseas distributors } \\
\text { +Innovation } \\
\text { +Niche marketing } \\
\text { +Acquisition } \\
\text { +Market leader }\end{array}$ & $\begin{array}{l}\text { Emergent (born } \\
\text { global) then } \\
\text { Transformational } \\
\text { (takeover, trade } \\
\text { sale) }\end{array}$ \\
\hline $\begin{array}{l}\text { Cedenco Foods (1986) } \\
* \text { wholly owned } \\
\text { subsidiary of Imanaka } \\
\text { Co Ltd (Japan) } 2010\end{array}$ & $\begin{array}{l}\text { Small } \\
\text { Primary } \\
\text { (food } \\
\text { process.) }\end{array}$ & Slow & $\begin{array}{l}\text { Local } \\
\text { Top } 4\end{array}$ & $\begin{array}{l}\text { Exporting } \\
\text { Investment (JV, } \\
\text { acquisition, sales) }\end{array}$ & $\begin{array}{l}\text {-FoREX } \\
\text { +offshore demand } \\
\text { +Market research } \\
\text { +Capability, efficiency }\end{array}$ & $\begin{array}{l}\text { Traditional } \\
\text { Transformational } \\
\text { (takeover, trade } \\
\text { sales x 2) }\end{array}$ \\
\hline $\begin{array}{l}42 \text { Below (1996) } \\
\text { (sold to Bicardi 2006) }\end{array}$ & $\begin{array}{l}\text { Small } \\
\text { Primary } \\
\text { (distillery) }\end{array}$ & $\begin{array}{l}\text { Rapid } \\
\text { (late) }\end{array}$ & $\begin{array}{l}\text { Top } 4 \text { (US) } \\
\text { Niche }\end{array}$ & Exporting & $\begin{array}{l}\text { +Brand } \\
\text { +Creativity }\end{array}$ & $\begin{array}{l}\text { Emergent } \\
\text { (born again global) } \\
\text { Transformational } \\
\text { (trade sale) }\end{array}$ \\
\hline Peter Lynn Kites (1973) & $\begin{array}{l}\text { Small } \\
\text { Secondary } \\
\text { (manufacture) } \\
\end{array}$ & Slow & Top 4 & $\begin{array}{l}\text { Exporting } \\
\text { Outsourcing } \\
\text { Investment (JV) }\end{array}$ & $\begin{array}{l}\text {-Small NZ market } \\
\text {-Labour costs } \\
\text { +Innovation }\end{array}$ & Traditional \\
\hline $\begin{array}{l}\text { LifeStream International } \\
\text { (1980) }\end{array}$ & $\begin{array}{l}\text { Small } \\
\text { Secondary } \\
\text { (manufacture) }\end{array}$ & Slow & $\begin{array}{l}\text { Top } 4 \\
\text { Emergent }\end{array}$ & $\begin{array}{l}\text { Exporting } \\
\text { Networks (partnerships, } \\
\text { alliances) }\end{array}$ & $\begin{array}{l}\text { +Quality } \\
\text { +Innovation }\end{array}$ & Traditional \\
\hline TigerTurf (1981) & $\begin{array}{l}\text { Small } \\
\text { Secondary } \\
\text { (manufacture) }\end{array}$ & $\begin{array}{l}\text { Slow } \\
\text { (late) }\end{array}$ & Emergent & $\begin{array}{l}\text { Exporting } \\
\text { Investment (sales } \\
\text { subsidiary) }\end{array}$ & $\begin{array}{l}\text {-Int. competition } \\
\text {-Transport delays } \\
\text { - tariff costs } \\
+ \text { Quality }\end{array}$ & $\begin{array}{l}\text { Emergent } \\
\text { (born again global, } \\
\text { diverse markets) }\end{array}$ \\
\hline $\begin{array}{l}\text { Right Hemisphere } \\
\text { (1997) } \\
\text { *Acquired by SAP } 2011\end{array}$ & $\begin{array}{l}\text { Small } \\
\text { Tertiary } \\
\text { (software) }\end{array}$ & Rapid & Niche & $\begin{array}{l}\text { Exporting } \\
\text { Network - Partnerships }\end{array}$ & $\begin{array}{l}\text {-capital } \\
\text { +Innovation } \\
\text { +Networks } \\
\text { +Government loan }\end{array}$ & $\begin{array}{l}\text { Emergent } \\
\text { (born global) }\end{array}$ \\
\hline $\begin{array}{l}\text { AdvanceRetail } \\
\text { Technology (1998) } \\
\text { (acquired by 3Q } \\
\text { Holdings 2007) }\end{array}$ & $\begin{array}{l}\text { Small } \\
\text { Tertiary } \\
\text { (software) }\end{array}$ & $\begin{array}{l}\text { Slow } \\
\text { (late) }\end{array}$ & $\begin{array}{l}\text { Local } \\
\text { Emergent } \\
\text { (Asia) }\end{array}$ & $\begin{array}{l}\text { Investment (sales sub, } \\
\text { merger) } \\
\text { Network (alliances) }\end{array}$ & $\begin{array}{l}\text { +Niche focus } \\
\text { +Relationships with } \\
\text { market leaders }\end{array}$ & $\begin{array}{l}\text { Emergent (born } \\
\text { again global) } \\
\text { Transformational } \\
\text { (trade sale) }\end{array}$ \\
\hline Fastway Couriers (1983) & $\begin{array}{l}\text { Small } \\
\text { Tertiary } \\
\text { (courier } \\
\text { franchise) }\end{array}$ & Slow & $\begin{array}{l}\text { Local } \\
\text { Niche } \\
\text { (Ireland, } \\
\text { S.Africa) }\end{array}$ & Franchising & $\begin{array}{l}\text {-Capital } \\
\text {-Small NZ market } \\
\text { +Customer Proximity } \\
\text { +Franchising } \\
\text { +Market research }\end{array}$ & $\begin{array}{l}\text { Traditional } \\
\text { (service) }\end{array}$ \\
\hline $\begin{array}{l}\text { Black Coffee Software } \\
(2000)\end{array}$ & $\begin{array}{l}\text { Small } \\
\text { Tertiary } \\
\text { (software) }\end{array}$ & Rapid & $\begin{array}{l}\text { Top } 4(\mathrm{UK}) \\
\text { Niche }\end{array}$ & Exporting & +Innovation & $\begin{array}{l}\text { Emergent } \\
\text { (born global) }\end{array}$ \\
\hline $\begin{array}{l}\text { Mariner-7 (2001) } \\
\text { StaffCV (2002) }\end{array}$ & $\begin{array}{l}\text { Small } \\
\text { Tertiary } \\
\text { (software) }\end{array}$ & Rapid & $\begin{array}{l}\text { Local } \\
\text { Niche }\end{array}$ & $\begin{array}{l}\text { Exporting } \\
\text { Investment (sales } \\
\text { subsidiaries) }\end{array}$ & $\begin{array}{l}\text {-Niche product } \\
\text { +Innovation } \\
\text { +Networks }\end{array}$ & $\begin{array}{l}\text { Emergent then } \\
\text { Transformational } \\
\text { (strategic partner) }\end{array}$ \\
\hline
\end{tabular}

*Case material was limited to the period from the time of establishment until 2008 in order to allow for time lagged effects. Any major changes that may have affected the firm's internationalisation since this cut-off date are given under the company name $($ see *)

$\wedge$ Drivers and constraints are internal, external, +positive or -negative influences 
Figure 1 Dimensions of Internationalisation

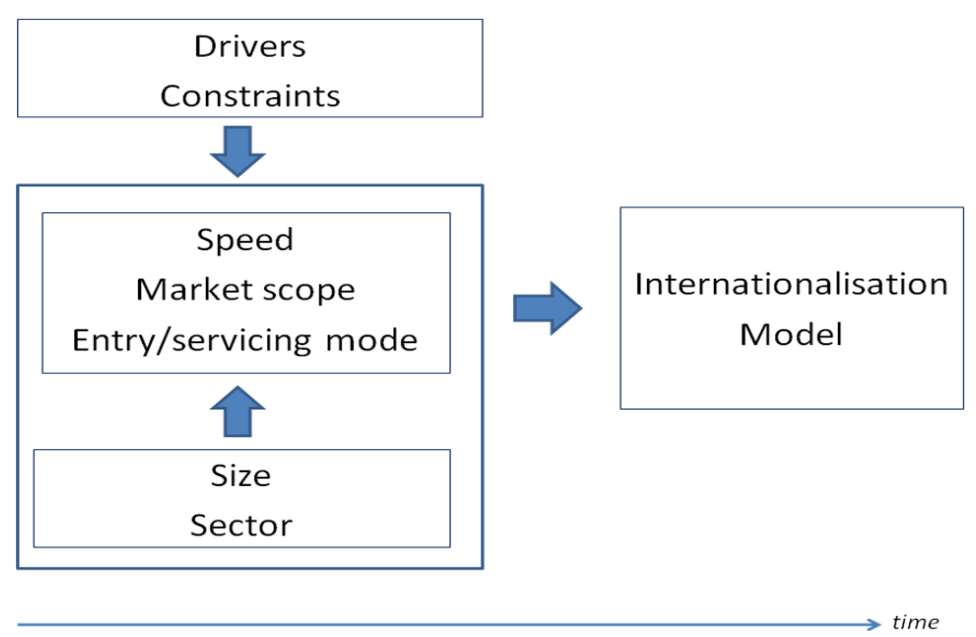


Table 1a Dimensions of Internationalisation - Size, Sector and Speed $(\mathrm{n}=30)$

\begin{tabular}{lrlrlr}
\hline \multicolumn{1}{c}{ Size } & \multicolumn{2}{c}{ Sector } & \multicolumn{2}{c}{ Speed } \\
\hline Small & 10 & Primary* & 8 & Slow & 64 \\
Medium & 9 & Secondary & 11 & Rapid & 6 \\
Large & 11 & Tertiary^ & 11 & & \\
\hline
\end{tabular}

*Primary = natural resource-based sectors, primary processing and food manufacturing.

$\wedge$ Tertiary $=$ services and/or sales, including firms producing customised software

Table 1b Dimensions of Internationalisation - Market Scope and Entry Modes $(\mathrm{n}=30)$

\begin{tabular}{lcclr}
\hline Market Scope & Cumulative & Current & Entry/Servicing Modes & \\
\hline Local & 17 & 1 & Exporting & 24 \\
Top 4 & 14 & 4 & FDI & 22 \\
Emergent & 11 & 11 & Networks & 10 \\
Niche & 7 & 8 & Outsourcing & 7 \\
Mass & 4 & 4 & Licensing & 3 \\
Global & 2 & 2 & Franchising & 1 \\
\hline
\end{tabular}

*Tallies for cumulative market scope and core entry modes do not sum to 30 as total market coverage over the lifecycle of the firm is taken into account.

Table 1c Dimensions of Internationalisation - Drivers and Constraints $(\mathrm{n}=30)$

\begin{tabular}{|c|c|c|c|}
\hline \multicolumn{4}{|c|}{ Drivers and Constraints to Internationalisation } \\
\hline Positive, internal & & Negative, external & \\
\hline Innovation, technology & 13 & NZ market size & 5 \\
\hline Networks, partnerships & 8 & Foreign exchange rates & 4 \\
\hline Knowledge, skills & 6 & Capital constraints & 4 \\
\hline Brand or design & 4 & Competition & 3 \\
\hline Marketing & 4 & Trade restrictions, quotas & 3 \\
\hline $\begin{array}{l}\text { Market opportunities; Niche focus; Market } \\
\text { research; Scale or scope }\end{array}$ & $\begin{array}{r}3 \\
\text { each }\end{array}$ & & \\
\hline
\end{tabular}

*Tallies for cumulative market scope and core entry modes do not sum to 30 as total market coverage over the lifecycle of the firm is taken into account.

Table 2 Internationalisation Models - New Zealand Firms ( $\mathrm{n}=30)$

\begin{tabular}{lccccc}
\hline \multicolumn{1}{c}{ Traditional } & \multicolumn{1}{c}{ Emergent } & \multicolumn{2}{c}{ Transformational* } \\
\hline $\begin{array}{l}\text { Natural-resource based } \\
\text { primary processors }\end{array}$ & $7(4)$ & $\begin{array}{l}\text { Born global } \\
\text { Born again global }\end{array}$ & $\begin{array}{l}5(2) \\
\text { Other (1) }\end{array}$ & Trade sale (incl. takeovers) & 9 \\
$\begin{array}{l}\text { Manufacturers, services, } \\
\text { sales (incl. construction } \\
\text { and retail) }\end{array}$ & $14(3)$ & $\begin{array}{l}\text { Othent } \\
\text { markets, collaborative } \\
\text { advanced modes) }\end{array}$ & $3(1)$ & International divestment & 2 \\
\hline Totals & $21(7)$ & & $9(4)$ & 11 \\
\hline
\end{tabular}

*All transformational firms are also included in tallies for traditional or emergent models, in parentheses (). 